\title{
Status of Coral Health and Disease in Kessilampe Waters, Kendari, South East Sulawesi
}

\author{
Ratna Diyah Palupi ${ }^{1 *}$, Rahmadani $^{2}$ and $\operatorname{Ira}^{1}$ \\ ${ }^{1}$ Department of Oceanography, Faculty of Fisheries and Marine Science, Halu Oleo University \\ Campus Hijau Bumi Tridharma Anduonohu Kendari Indonesia 93232 \\ 2Department of Marine Science, Faculty of Fisheries and Marine Science, Halu Oleo University \\ Campus Hijau Bumi Tridharma Anduonohu Kendari Indonesia 93232 \\ Email: palupi_rd@yahoo.com
}

\begin{abstract}
Diseases of coral reef organisms have become a global threat to coral reefs and a major cause of reef deterioration. The presence of coral diseases influence marine resources productivity that interact with coral reefs. The purpose of this research is to identify coral disease types and prevalence which include coral health compromiser. Data collection was done by using $40 \mathrm{~m}^{2}$ belt transects at three observation stations. The result showed that the White Syndrome (WS), Bleaching, Ulcerative White Spot (UWS), Skeleton Eroding Band (SEB), White Patch (WP), and Non Focal Bleaching were found at research sites, while the coral health compromisers were Sediment damage, fish bite, invertebrate galls, flatworm infestation, and pigmentation response. In addition disease of White Syndrome (WS), Bleaching, and Ulcerative White Spot (UWS) were the main disease with prevalence of disease is approximately 4\%, while the others were lower than $1 \%$. Overall the prevalence of diseases $(14,52 \%)$ is higher than compromise health (13,98\%). A total of 186 coral colonies observed with 27 colonies were affected by diseases. Meanwhile, the waters quality (salinity, $\mathrm{pH}$, and nitrate) were below the threshold quality standards for marine aquatic animal and not supported of coral organism was presume organisms against pathogens bacterial. Although the prevalence of coral disease is still in normal condition but the decrease of water quality can lead the risk. Good management is required from local government to improve the water quality especially from terrestrial impact.
\end{abstract}

Key words: compromise health; coral disease identification; prevalence

\section{Introduction}

Coral reef ecosystem is more complex association than seagrass and mangrove. Some animals (vertebrate and a-vertebrate) such as Mollusca, Polychaeta, Crustaceans, fish species and sea mammalians have interact and make a stable and balanced ecosystem. Unfortunately, instability on coral reef ecosystems can reduce the quality of coastal resources in these habitats. In addition If the house are damaged and degraded, then it implies to the marine biota it will also be disrupted. One of damage that can occur in coral reef is a disease caused by microorganisms (Castro et al., 2010).

Besides of uni-cell algae (zooxanthellae), coral organism also have a symbiotic relationship with bacteria that present in the body tissue or in the water (Carter, 2013). More than 10,000 bacteria are found in sediment of coral reefs or in the body of coral (coral tissue). This type of bacteria can be become good bacteria as well as bad bacteria. The bad bacteria that are pathogenic and cause disease in corals. In addition to bacteria, there are many causes of coral diseases, which are caused by viruses, fungi, or other animals (Raymundo and Harvell, 2008). The disorder caused by coral diseases have been studied but not many that describe the physical aspect (Richardson et al., 2009). In fact, damage to coral reefs can be caused by a symbiosis with the coral organisms that are pathogenic microorganisms. On the other hand, bad bacteria or microbial agent(s) often correlate with the appearance of signs of diseases and/or bleaching, thus suggesting a link between microbes, coral health and the stability of reef ecosystems (Krediet et al., 2013). As to this hypothesis, there does not appear to be a consensus about specificity in the interactions of corals with 
microbial commensalisms. They cycle of sulphur, fix nitrogen, produce antimicrobial compounds, inhibit cell-to-cell signaling and disrupt virulence in opportunistic pathogens.

Coral disease also be caused by non-biotic agents, such as by pollution, water sedimentation, temperate change and nutrient enrichment (Lourie et al., 2008). One potential factor is elevated nutrient concentration related to localized anthropogenic activities such as inadequate waste water treatment or terrestrial runoff. Voss and Richardson (2006) reported that both experimental and laboratory increases in localized nutrient availability using commercial time release fertilizer in situ resulted in doubling of $\mathrm{BBD}$ progression and coral tissue loss in the common reef framework coral Siderastrea sidereal. Reef location was found to be the most significant influence on the coral-bacterial community. It is possible that more pronounced lesion-specific bacterial signatures might have been concealed by the strong influence of environmental conditions on coral-bacteria (Apprill et al., 2013).

Several studies have concluded that coral diseases caused by bacteria are the biggest cause of damage to coral reefs in the world even some waters in Indonesia (Page, 2009; Kellogg et al., 2014). For example, coral disease white plague and white band that had attacked the waters of the Caribbean Sea which occurred on coral Acropora species (Miller et al., 2009; Chong Seng et al., 2010). This study aims is to identify of coral disease types at the study site.

\section{Materials and Methods}

Research was carried out for two months, April-May 2016, it is located at Mayaria beach and Bungkutoko, Kessilampe Waters, Kendari SE Sulawesi. The point of station is taken place based on the existence of coral organism were first discovered at the sites. Three stations which consists of two at the Mayaria beach (Station 1 and 2) and one at outside the coastal resorts, the Bungkutoko Island as comparators station (Station 3) (Figure 1.). Station 1 (03 $58^{\prime} 23.3^{\prime \prime} L S$ $122^{\circ} 36^{\prime} 07.4^{\prime \prime}$ BT): Many dead coral with algae (DCA) and soft coral (SC) were found. Coral organism was found in small spots and dominated with massive and foliose. Station 2 (03 ${ }^{\circ} 58^{\prime} 20.3^{\prime \prime}$ LS $122^{\circ} 36^{\prime} 08,8^{\prime \prime}$ BT): Many dead coral with algae (DCA) and soft coral (SC) were found. Most of the coral in bleaching conditions. Station 3 (03 58,496 'LS$\left.122^{\circ} 36,836^{\prime} \mathrm{BT}\right)$ : this station in Bungkutoko Island that is in front of the beach. Most of coral in bleaching conditions that dominated by massive corals.

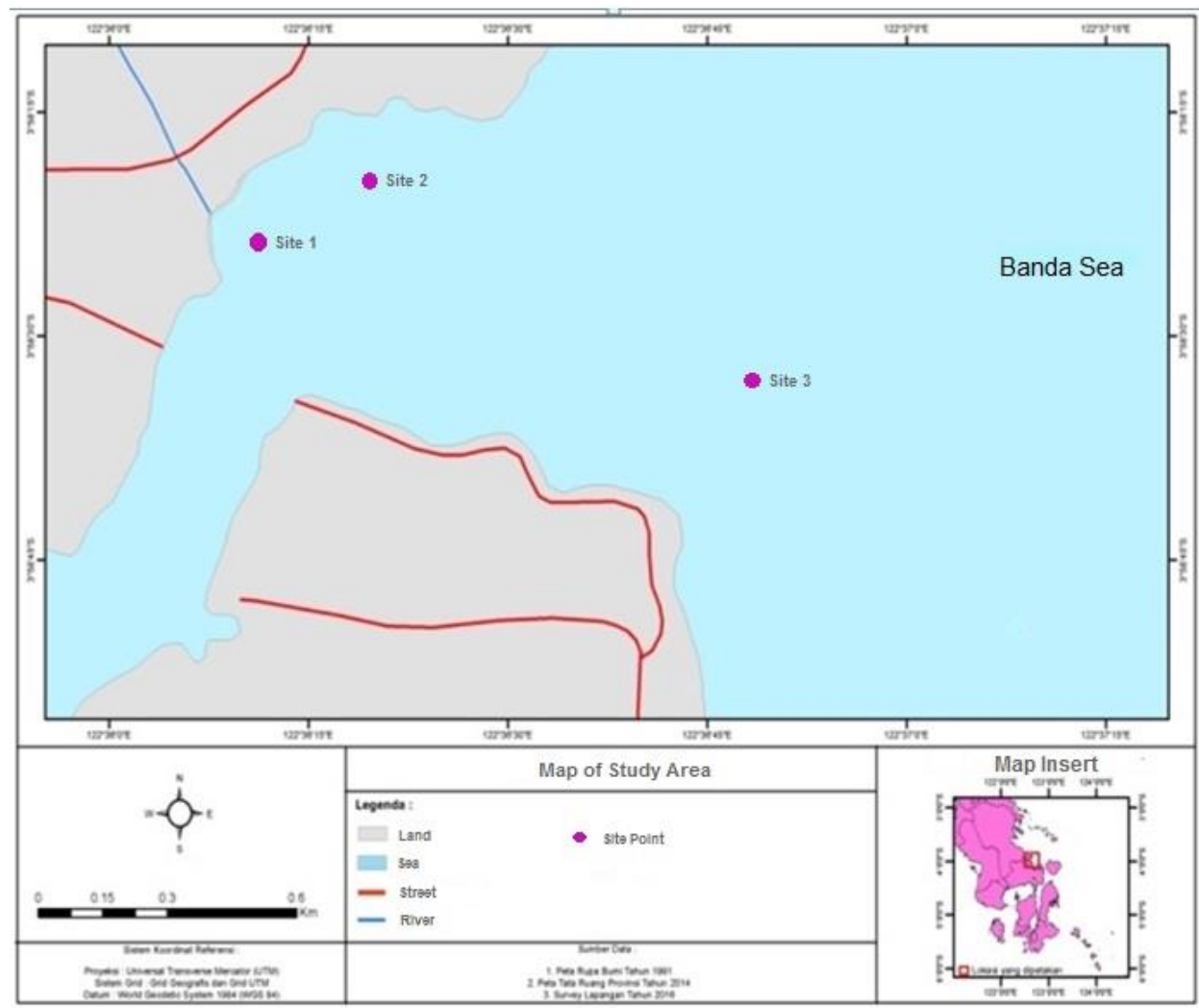

Figure 1. Map of study area Kessilampe Waters 
Samplings of disease prevalence were taken using belt transect $20 \mathrm{~m} \times 2 \mathrm{~m}\left(40 \mathrm{~m}^{2}\right)$ along $50 \mathrm{~m}$ of line transect with two times of replication (Weil et al., 2008). Each coral colony within the belt transect was calculated and recorded as healthy, infected, and compromise health (as addition information).

Prevalence of each disease was calculated by recording the number of coral infected by microorganism and total number of healthy corals per unit area. Furthermore all kinds of diseases and compromise health that founded were recorded, identified, and photographed with underwater camera. Identify the types of coral disease was done by visual observation and then analyzed using Sabdono et al. (2014) and Johan et al. (2017). In addition for the secondary data was water physical and chemical are also taken as supporting data.

\section{Results and Discussion}

Based on investigations, there are 6 (six) diseases and 5 (five) as coral health compromiser found in the study site with total of prevalence value were $14.52 \%$ and $13.98 \%$ (Figure 2. and 3.). Disease of White Syndrome (WS), Bleaching, and Ulcerative White Spot (UWS) are the main disease in research location with prevalence of disease is approximately $4 \%$, while the others were lower than $1 \%$. According to the research station, the number of disease in Mayaria Beach (5) was higher than Bungkutoko Island (3). In addition the compromise health just presence in Mayaria Beach with Sediment Damage was dominated in this location (6.45\%) (Figure 3.). Many factors may compromise coral health, but the main factor compromising coral health in Mayaria Beach was sedimentation and human activities in coast development, coral predator such as parrot fish and trigger fish (puffer fish), and competition with other organisms (soft coral and algae).

The number of disease in Kessilampe waters was slightly higher than reported cases in Panjang Island (4 types) (Sabdono et al., 2014) and Saponda Laut Island (5 types) (Hazrul et al., 2016). Furthermore, compared to other studies in Indonesia, the prevalence of disease in Kessilampe waters is higher than Saponda Laut Island (3.20\%) but lower than Panjang Island (74,37\%) (Hazrul et al., 2016; Sabdono et al., 2014). The waters characteristics that are not supported of coral organism was presume organisms against pathogens bacterial.

Furthermore the water quality such as of $\mathrm{pH}$, salinity, and nitrate at stations 1 and 2 (Mayaria
Beach) are below the threshold quality standards for aquatic animal (6, 23 ppm, 0,004mg. $\left.\mathrm{L}^{-1}\right)$ (Table 1.). These were conjecturable affected to the immune system of coral organism. The immune system will also vary depending on coral species in receiving from environmental stressors (Palmer, 2010). For instance Pocilloporidae and Aroporidae have low immune while Fungiidae and Poridae have high immunity (Palmer, 2010). Carter (2013) said that in addition to zooxanthellae, the coral organisms also have symbiotic with microorganisms (bacteria, viruses, and fungi). The pathogenic microorganisms will be carrier of diseases into coral organism. The amount of pollutants such of domestic waste from human activities have contributed to the existence of coral diseases, especially in Mayaria Beach (Stations 1 and 2) compared to the third station (Bungkutoko Island). In addition there are three kind of potential stressor of coral disease which is hosts, agent and environmental were participated presence of pathogenic microorganisms. For instance, rise of water temperature can result black band disease. An increase of temperature can also lead decreasing coral immunity and can instead pathogenic microorganisms would be more deadly (Raymundo and Harvell, 2008).

\section{Coral disease identification}

There were 6 (six) kinds of disease infected within transect and description. White Syndrome (WS): White syndrome disease is characterized by the loss of coral tissue due to non predation (Figure 4a.). Types of injury to the WS showed irregular and white. Many types of WS attacks the coral organism at Stations 1 and 2 in particular coral foliose, which strike at the central or middle. This disease is dominant in Mayaria Beach and infected 8 colonies with number of prevalence $4.30 \%$. White Patch (WP): Although extremely rare, the disease was found infecting white patch reef biota in Mayaria Beach (Station 2). This disease is rare in study site with prevalence value is $0.54 \%$ (one colony).

Ulcerative White Spot (UWS): Types of diseases characterized by loss of coral tissue but not due to predation. In contrast to the signs of the disease white syndrome, type of injury to the UWS showed a white spot (diameter $<1 \mathrm{~cm}$ ) spread evenly. The case in the study site, UWS disease infects coral organism with a prevalence is $3.76 \%$ ( 7 colonies) that infected foliose and massive corals (Figure 4b). Most cases of this disease are infected in the same corals (foliose) in Stations 1 and 2.

Bleaching and Non Focal Bleaching: Bleaching is classified as a type of disease that is not characterized by the loss of coral tissue. 
Bleaching is caused by changes color of the coral tissue, which becomes white but the coral (polyp) is actually still there. Bleaching disease at the study site dominated at Station 3 (Bungkutoko waters) with prevalence of $4.30 \%$ or at least 8 colonies affected by bleaching. The bleaching phenomenon occurs due to the effect of El-nino which occurred in Indonesian waters the end of the year 2015. The results of measurements of BMKG (2015) note that South Oscillation Index (SOI) in Indonesia on MayJuly 2015 was -10 which is an indicator of El-Nino or there has been a rise in the extreme annual temperature of $2^{\circ} \mathrm{C}$. The rise of temperature water make zooxanthellae algae become stressed and break away from its host network (coral) (Bhagooli and Hidaka, 2004). The loss of zooxanthellae into the waters significantly occurs at temperature of 30$32^{\circ} \mathrm{C}$. Further Shenkar et al. (2006) states that after the effect of the bleaching of coral biota will get back the zooxanthellae in normal amounts. Recovery rate after bleaching depends on water conditions. The more healthy the water, the faster the zooxanthellae algae also glued back on coral endodermis network. So it can be presumed that the Station 3 (Bungkutoko Island) is still the possibility biota experienced coral bleaching will be back to normal (recovery phase) if the water temperature has been normal $\left(28-29^{\circ} \mathrm{C}\right)$.

Skeleton Eroding Band (SEB): Prevalence of SEB was $1.08 \%$ or two colonies was infected of this disease. The infected coral in this location was massive coral ( 1 colony) and encrusting (1 colony). This disease also reported in SE Sulawesi Waters which is in Saponda Laut Island with prevalence was (Hazrul et al., 2016).

\section{Coral health compromiser identification}

Fish bite: The compromise health is characterized by loss of coral tissue due to predation or grazing by other organisms (Figure 5a.). Types of

Table 1. The present research result of physical-chemical oceanography in Mayaria Beach

\begin{tabular}{|c|c|c|c|c|c|c|}
\hline \multirow{2}{*}{ No } & \multirow{2}{*}{ Parameters } & \multirow{2}{*}{ Unit } & \multicolumn{3}{|c|}{ Station } & \multirow{2}{*}{$\begin{array}{c}\text { Source: standardization } \\
\text { of water quality for aquatic animal } \\
\text { (Kepmen LH No.51 2004) }\end{array}$} \\
\hline & & & 1 & 2 & 3 & \\
\hline 1 & Depth water & $\mathrm{m}$ & 8 & 5 & 2 & \\
\hline 2 & Surface temperature & ${ }^{\circ} \mathrm{C}$ & 29 & 29 & 31 & $28-30$ \\
\hline 3 & Depth temperature & ${ }^{\circ} \mathrm{C}$ & 29 & $28 *$ & 29 & \\
\hline 4 & Current velocity & $\mathrm{m} \cdot \mathrm{s}^{-1}$ & & 0,04 & 0,05 & \\
\hline 5 & Water transparency & $\mathrm{cm}$ & 50 & 100 & 200 & \\
\hline 6 & Salinity & ppt & $26 *$ & $20 *$ & $24 *$ & $33-34$ \\
\hline 7 & $\mathrm{pH}$ & & $6 *$ & $6 *$ & $6 *$ & $7-8,5$ \\
\hline 8 & Light & lux & 13,9 & 43,1 & 57,5 & \\
\hline 9 & Phosphate & mg.t-1 & \multicolumn{3}{|c|}{0,024 (average) } & 0,015 \\
\hline 10 & Nitrate & mg.t-1 & \multicolumn{3}{|c|}{$0,004 *$ (average) } & 0,008 \\
\hline
\end{tabular}

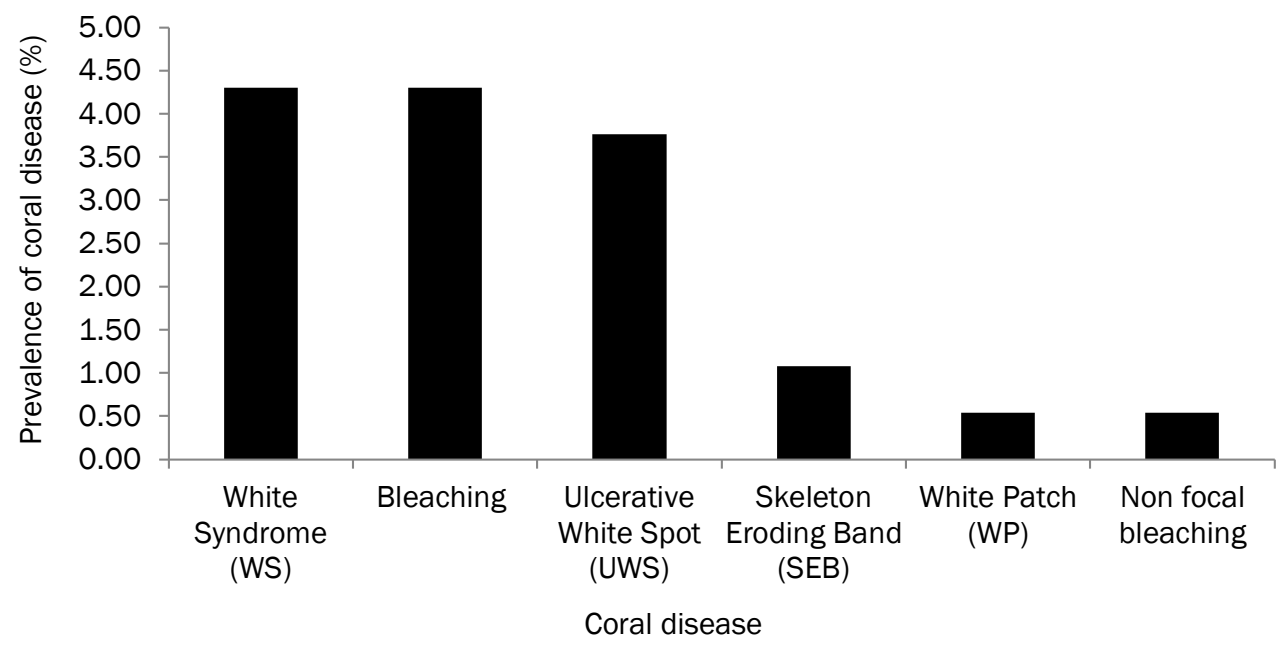

Figure 2. Coral disease prevalence in Kessilampe Waters 


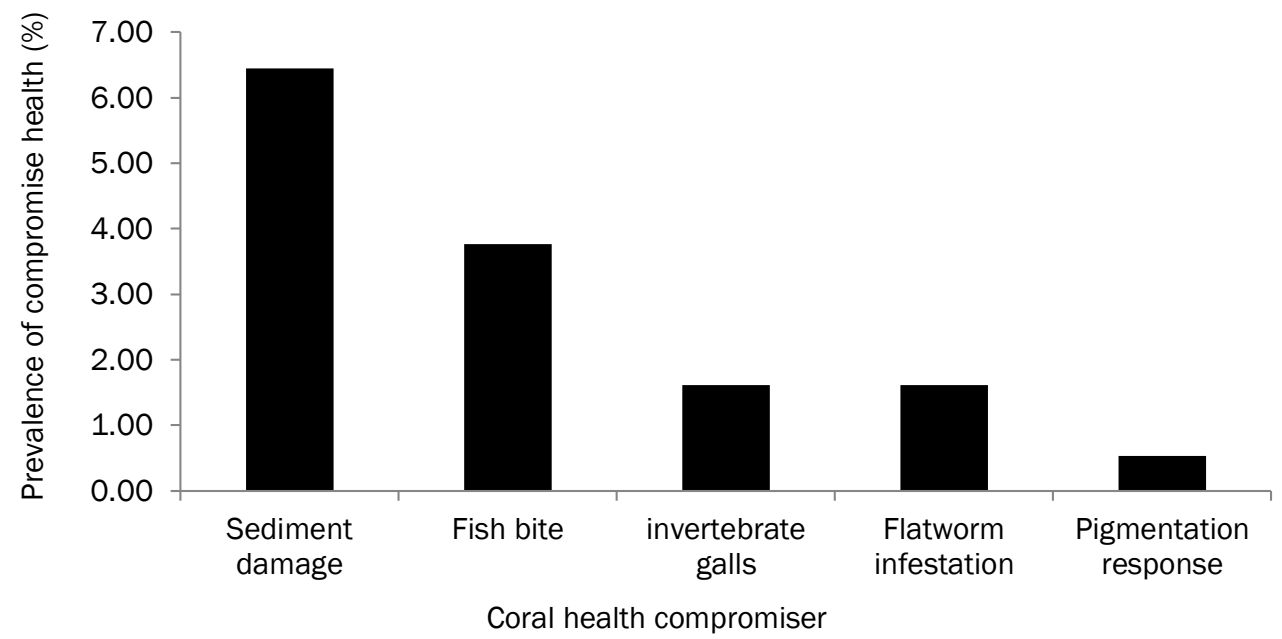

Figure 3. Coral health compromiser prevalence in Kessilampe Waters

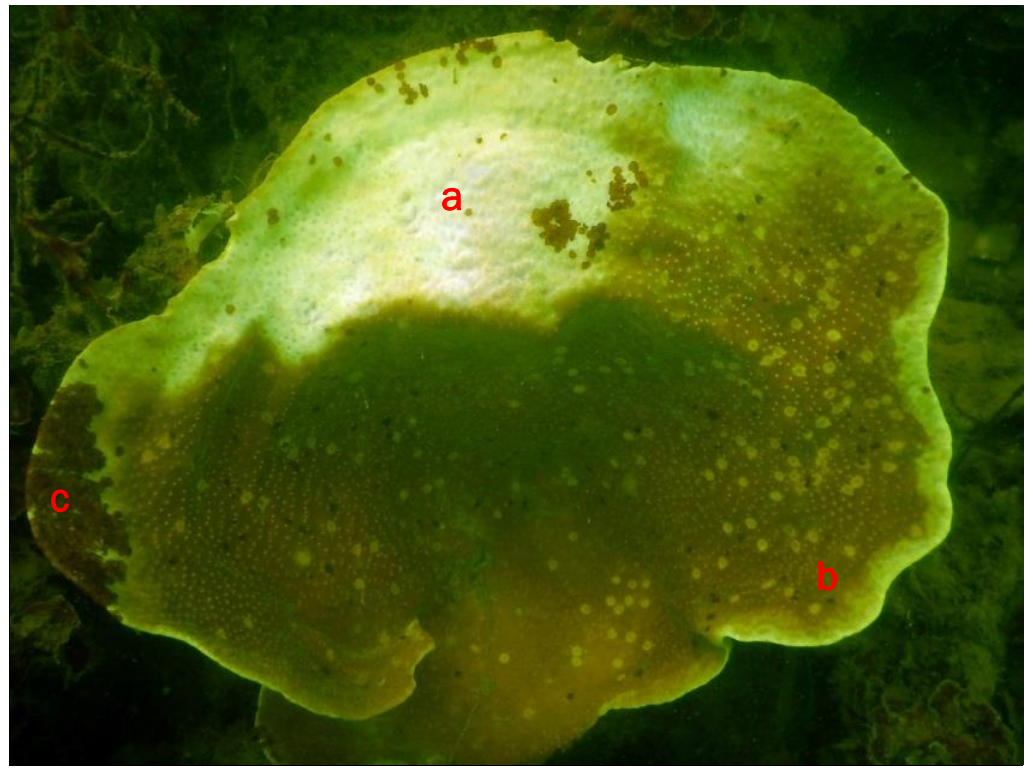

Figure 4. Two difference of coral disease (a) White Syndrome; (b) Ulcerative White Spot and one kind of compromise health (c) Flatworm infestation in coral foliose

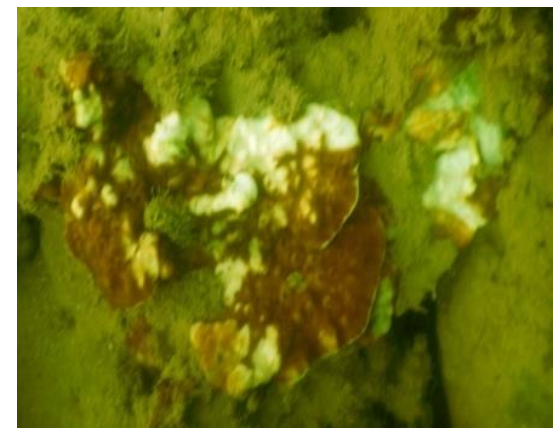

(a)

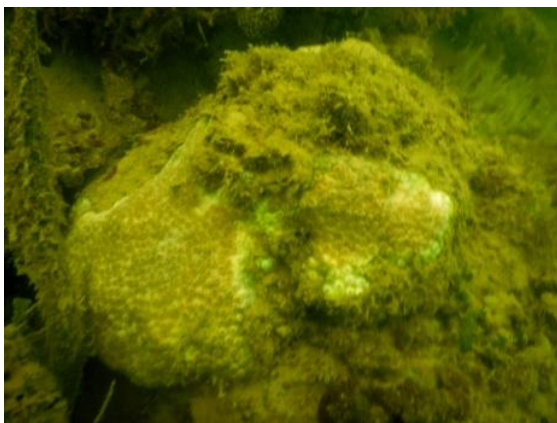

(b)

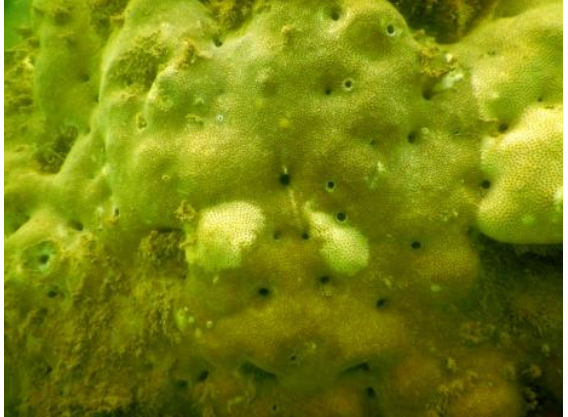

(c)

Figure 5. Coral health compromiser, (a) fish bite; (b) Sediment Damage; (c) Pigmentation Response 
fish bite of the study sites are mainly caused by parrot fish and trigger fish (puffer fish) and contained all station in Mayaria. The characteristics of the lesion is white patches with covering irregular and generally infected coral massive and sub massive. The existence of grazing fish in the study area can be used as a signal of the compromise health. For example parrotfish will graze algae attached to the reef, causing the coral tissue is torn and finally died (white). Usually the scars caused of fish bite will soon be overgrown by algae. The prevalence of fish bite in Mayaria Beach was 3.76\% with seven of coral colony was infected.

Sedimen damage: This compromise health was dominated at study area (Station 1 and 2) (Figure 5b.). The location was situated at the mouth of Kendari Bay in which the commercial ships regularly enter that palace. Consequently it can lead high sedimentation in Mayaria Beach. The Sedimentation can lead coral mortality and also the emergence of pathogenic microorganisms in the water (Raymundo and Harvell, 2008; Johan et al., 2017). No sedimentation data was conducted in our study, but there were data of Total Suspended Solid (TSS) from Kendari Bay, located close the study sites, showing TSS was range of 672-781 mg.L-11 (Winnarsih and Emiyarti, 2016). Sediment particles floating in the water column can eventually cover the polyp that will experience illness due to covered with sediment. Furthermore low salinity and $\mathrm{pH}$ are makes the reef biota that live in this area have a low immune system (Table 1.). Palupi et al. (2017) said that the percentage of coral cover in study site was in bad category which is an average of $19 \%$.

Pigmentation response: Early identification of this compromise health is loss of coral tissue color instead of white. Usually, the color changes to pink or purple point type or spread. Pigmentation response at the site location attack one coral massive from Poritidae with prevalence value was $0.54 \%$. Pink color appears spread out and tend to be brighter than the color of a healthy reef, followed by injuries (Figure 5c).

Invertebrate galls: The coral health compromiser is caused by invertebrate animals, in this case bernacle are dig on the surface of the reef. Consequently reef biota will be hurt and this may provide an opportunity coral pathogens that attack animals. Usually the former drill of the invertebrate animals over grown with algae or covered by sediment. There are three coral colony was infected with prevalence value was $1.61 \%$.

Flatworm infestation: This compromise health disturb three colonies of coral with prevalence value was $1.61 \%$. Brown flatworms are infected foliose and submasive corals in Station 1 (Figure 4c.). Many of domestic wastes in Mayaria Beach as coastal tourism was indicated causative agent for this infestation. Brown flatworms is notably in the genus Waminoa with brown coloration due to endosymbiotic dinoflagellates (Beeden et al., 2008).

\section{Conclusion}

There are 6 types of coral diseases and 5 types of compromise health found in the research location. White Syndrome (WS) and Bleaching are the mainly disease both in Mayaria Beach and Bungutoko Island while Sediment Damage is dominance for compromise health in Mayaria Beach. The total coral disease prevalence in Kessilampe waters was $14.52 \%$.

\section{Acknowledgement}

We acknowledge fieldwork by Cilly, Asmiati, Tomo S., and Rorin S. This paper is one of the research elements of the Higher Education research grant competition the Ministry of Technology, Research and Higher Education 2016. We are grateful for funding supported grant from DRPM DIPA 2016.

\section{References}

Apprill, A., Hughen, K. \& Mincer, T. 2013. Major similarities in the bacterial communities associated with lesioned and healthy Fungiidae corals. Environ. Microbiol. 15(7): 2063-2072. doi: 10.1111/1462-2920.12107

Beeden, R., Willis, R.B., Raymundo, L.J., Page, C.A. \& Weil, E. 2008. Underwater Cards for Assessing Coral Health on Indo-Pacific Reefs. CRTR. Australia

Bhagooli, R. \& Hidaka, M. 2004. Release of zooxanthellae with intact photosynthetic activity by the coral Galaxea fascicularis in response to high temperature stress. Mar. Biol. 145(2): 329-337.doi: 10.1007/s00227-004-1309-7

Badan Meteorologi, Klimatologi, dan Geofisika (BMKG). 2015. Sejarah Dampak El Nino di Indonesia. www.bmkg.go.id/BMKG.

Carter, A. 2013. Corals Indispensable Bacterial Buddies. Oceanus. 50(2): 6-7 
Chong-Seng, K.M., Cole, A.J., Pratchett, M.S. \& Willis, B.L. 2011. Selective feeding by coral reef fishes on coral lesions associated with brown band and black band disease. Coral Reefs. 30(2): 473-481. doi: 10.1007/s00338-010-0707-1

De Castro, A.P., Araújo, S.D., Reis, A.M., Moura, R.L., Francini-Filho, R.B., Pappas, G., Rodrigues, T.B., Thompson, F.L. \& Krüger, R.H. 2010. Bacterial community associated with healthy and diseased reef coral Mussismilia hispida from eastern Brazil. Microb. Ecol. 59(4): 658-67. doi: 10.1007/s00248-010-9646-1

Hazrul, H., Palupi, R.D. \& Ketjulan, R. 2016. Identifikasi Penyakit Karang (Scleractinia) di Perairan Pulau Saponda Laut, Sulawesi Tenggara J. Sapa Laut. 1(2): 32-41

Johan, O., Ginanjar, R. \& Priyadi, A. 2017. Coral health levels of wild ornamental coral in East Belitung Waters, Indonesia. J. Nasional. 7(2): 133-138

Kellogg, C.A., Piceno, Y.M., Tom, L.M., De Santis, T.Z., Gray, M.A. \& Andersen, G.L. 2014. Comparing bacterial community composition of healthy and dark spot-affected Siderastrea siderea in Florida and the Caribbean. PLoS One. 9(10): e108767. doi: 10.1371/journal.pone.01087 67

Kementerian Lingkungan Hidup (KMNLH). 2004. Pedoman Penetapan Baku Mutu Lingkungan. Kantor Menteri Negara Kependudukan Lingkungan Hidup 2004. Keputusan Menteri Negara Kependudukan dan Lingkungan Hidup. Kep-51/MENEGLH/ 2004. Sekretariat Negara, Jakarta.

Kellogg, C.A., Piceno, Y.M., Tom, L.M., De Santis, T.Z., Gray, M.A. \& Andersen, G.L. 2014.Comparing bacterial community composition of healthy and dark spot-affected Siderastrea siderea in Florida and the Caribbean. PLoS One, 9(10): e108767. doi: 10.1371/journal.pone.01087 67

Krediet, C.J., Ritchie, K.B., Paul, V.J. \& Teplitski, M. 2013. Coral-associated micro-organisms and their roles in promoting coral health and thwarting diseases. Proc. Royal Soc. London B: Biol. Sci. 280 (1755): 20122328. doi: $10.1098 /$ rspb.2012.2328

Miller, J., Muller, E., Rogers, C., Waara, R., Atkinson, A., Whelan, K.R.T., Patterson, M. \& Witcher, B.,
2009. Coral disease following massive bleaching in 2005 causes $60 \%$ decline in coral cover on reefs in the US Virgin Islands. Coral Reefs, 28(4): 925-937. doi: 10.1007/s0033 8-009-0531-7

Page, C.A. 2009. Ecology and Biology of Coral Disease on The Great Barrier Reef. Ph.D Thesis. [http://eprints.jcu.edu.au/10533]. James Cook University. Australia.

Palmer, C.V. 2010. Biological mechanism of coral immunity. Ph.D Thesis. James Cook University. Australia

Palupi, R.D. Ira \& Rahmadani. 2017. Kesehatan Karang di Perairan Kessilampe Kota Kendari Berdasarkan Skor Kesehatan Karang dan Densitas Zooxanthellae. Omni-Akuatika. 12(3): 131-137.doi: 10.20884/1.oa.2016.12.3.162

Raymundo, L. \& Harvell, C.D. 2008. The Objectives and Scope of This Manual. In: Laurie J. Raymundo, Courtney S. Couch and C. Drew Harvell (Eds), A Coral Disease Handbook: Guidelines for Assessment, Monitoring and Management. Australia.

Richardson, L.L., Miller, A.W., Broderick, E., Kaczmarsky, L., Gantar, M. \& Sekar, R. 2009. Sulfide, microcystin, and the etiology of black band disease. Dis. Aquat. Organ. 87(1-2): 7990. doi: $10.3354 /$ dao02083.

Sabdono, A., Radjasa, O.K., Trianto, A., Wijayanti, D.P. \& Pringgenies, D., 2014. An early evaluation of coral disease prevalence on Panjang Island, Java Sea, Indonesia. Int. J. Zool. Res., 10(2): 20-29. doi: 10.3923/ijzr.2014. 20.29

Shenkar, N., Fine, M., Kramarsky-Winter, E. \& Loya, Y., 2006. Population dynamics of zooxanthellae during a bacterial bleaching event. Coral Reefs. 25: 223-227. doi: 10.1007/s00338-006-00 90-0

Voss, J.D. \& Richardson, L.L. 2006. Nutrient enrichment enhances black band disease progression in corals. Coral Reefs. 25(4): 569576. doi: 10.1007/s00338-006-0131-8

Winnarsih, W. \& Emiyarti, E. 2016. Distribusi Total Suspended Solid Permukaan di Perairan Teluk Kendari. J. Sapa Laut. 1(2): 54-59 
Weil E., Jordán-Dahlgren E., Bruckner, A. \& Raymundo L. 2008. Assessment and Monitoring Protocols. In: Laurie J. Raymundo, Courtney S. Couch and C. Drew Harvell (Eds), A
Coral Disease Handbook: Guidelines for Assessment, Monitoring and Management. Australia. 